\title{
THE MEANING ASSIGNED BY COUPLES TO PLANNED HOME BIRTH SUPPORTED BY NURSE MIDWIVES OF THE HANAMI TEAM
}

\author{
Vania Sorgatto Collaço ${ }^{1}$, Evanguelia Kotzias Atherino dos Santos ${ }^{2}$ Kleyde Ventura de Souza ${ }^{3}$, \\ Herdy Valdecyr Alves", Maria de Fátima Zampieri ${ }^{5}$, Vitória Regina Petters Gregório ${ }^{6}$
}

${ }^{1}$ Ph.D. in Nursing. Nurse of the University Hospital of the Universidade Federal de Santa Catarina (UFSC). Professor, Universidade do Sul de Santa Catarina. Florianópolis, Santa Catarina, Brazil. E-mail: parto.domiciliar@gmail.com

2 Ph.D. in Nursing. Professor, Nursing Department and Graduate Program in Nursing, UFSC. Florianópolis, Santa Catarina, Brazil. E-mail: gregos@matrix.com.br

${ }^{3}$ Ph.D. in Nursing. Professor, Public Health and Maternal and Child Nursing Department, Nursing School, Universidade Federal de Minas Gerais. Belo Horizonte, Minas Gerais, Brazil. E-mail: kleydeventura@uol.com.br

${ }^{4}$ Ph.D. in Nursing. Professor, Psychiatric and Maternal and Child Department, Escola de Enfermagem Aurora de Afonso Costa, Universidade Federal Fluminense. Niterói, Rio de Janeiro, Brazil. E-mail: herdyalves@yahoo.com.br

${ }^{5}$ Ph.D. in Nursing. Professor, Department and the Graduate Program in Nursing, UFSC. Florianópolis, Santa Catarina, Brazil. E-mail: fatimazampieri@gmail.com

${ }^{6}$ Ph.D. in Nursing. Professor, Nursing Department, UFSC. Florianópolis, Santa Catarina, Brazil. E-mail: vitoria@nfr.ufsc.br

\begin{abstract}
Objective: to understand the meaning assigned by couples to the experience of planned home birth supported by the nurse midwives of the Hanami team.

Method: qualitative study in the form of convergent care research developed with 30 couples in the southern region of Brazil within the period between October 2011 and November 2012. Data were collected through interview and participant observation. Analysis included four stages: apprehension, synthesis, theorization, and transfer.

Results: one core category was identified: Culturally respectful and sensitive delivery, pointing to a parturitive scenario expected by the couple, fueled by the belief that the professionals selected for this moment are able to understand the worldview, beliefs, values, rituals of care, and the meanings assigned to them; and three subcategories: The realization of an ideal, Birth with the family and The option for their home instead of a hospital.

Conclusion: the environmental context of a home implies the totality of a singular experience that respects the physical, holistic-ecological, emotional, and cultural dimensions of a couple, bringing up the home as the place of choice for the delivery. The positive experience of the couples makes up the meaning that the planned home birth is an ideal consistent with the lifestyle, beliefs, values, and culture, consisting in a reproductive and sexual right. Home birth is a new chance to interact with the world and people that are part of the support network to couples in the birth process.
\end{abstract}

DESCRIPTORS: Home childbirth. Obstetric nursing. Nurse midwives. Cultural characteristics. Care.

\section{O SIGNIFICADO ATRIBUIDO PELO CASAL AO PARTO DOMICILIAR PLANEJADO, ASSISTIDO PELAS ENFERMEIRAS OBSTÉTRICAS DA EQUIPE HANAMI}

\section{RESUMO}

Objetivo: conhecer o significado atribuído pelo casal acerca da experiência do parto domiciliar planejado, assistido pelas enfermeiras obstétricas da Equipe Hanami.

Método: estudo de natureza qualitativa, na modalidade de Pesquisa Convergente-Assistencial, desenvolvida com 30 casais, no Sul do Brasil, no período de outubro de 2011 a novembro de 2012. A coleta de dados foi realizada por meio de entrevista e observação participante. A análise compreendeu quatro etapas: apreensão, síntese, teorização e transferência.

Resultados: identificado uma categoria central: O parto culturalmente respeitoso e sensível, que aponta para um cenário parturitivo esperado pelo casal, alimentado na crença de que os profissionais escolhidos para compor este momento tenham a compreensão da visão de mundo, das crenças, dos valores, dos rituais de cuidados e dos significados que lhes são atribuídos; e por três subcategorias: A concretização de um ideal, O nascimento em família e A escolha do domicílio em detrimento do hospital.

Conclusão: o contexto ambiental do domicílio implica na totalidade de uma experiência singular que respeita as dimensões físicas, holísticoecológicas, emocionais e culturais do casal, trazendo à tona o domicílio como o local de escolha para a ocorrência do parto. A experiência positiva dos casais concretiza o significado de que o parto domiciliar planejado é um ideal coerente com o estilo de vida, crenças, valores, cultura e constitui-se num direito reprodutivo e sexual. O parto domiciliar é uma nova chance para interagir com o mundo e com pessoas que fazem parte da rede de apoio ao casal no processo de nascimento.

DESCRITORES: Parto domiciliar. Enfermagem obstétrica. Enfermeiras obstétricas. Características culturais. Assistência. 


\title{
EL SIGNIFICADO ATRIBUIDO POR LA PAREJA AL PARTO DOMICILIAR PLANEADO, ASISTIDO POR OBSTETRICAS DEL EQUIPO HANAMI
}

\begin{abstract}
RESUMEN
Objetivo: conocer el significado atribuido por la pareja sobre la experiencia del parto domiciliar planeado, asistido por enfermeras obstétricas del Equipo Hanami.

Métodos: investigación cualitativa, en la Modalidad de Investigación Convergente-Asistencial, desarrollada con 30 parejas en el Sur de Brasil, de octubre de 2011 a noviembre de 2012. La recolección de datos fue realizada por medio de entrevista y observación participante. El análisis comprendió cuatro etapas: aprensión, síntesis, teorización y transferencia.

Resultados: fue identificada una categoría central: El parto culturalmente respetuoso y sensible que apunta para un escenario partutitivo esperado por la pareja, alimentado en la creencia de que los profesionales seleccionados para componer este momento tengan la comprensión de la visión de mundo, de las creencias, de los valores, de los rituales de cuidados y de los significados que le son atribuidos; y por tres subcategorías: la concretización de un ideal, El nacimiento en familia y La elección del domicilio en lugar del hospital.

Conclusión: el domicilio implica la totalidad de una experiencia singular que respeta las dimensiones físicas, holístico-ecológicas, emocionales y culturales de la pareja, de ahí que nazca la elección del mismo para el parto. La experiencia positiva de las parejas concretiza el significado de que el parto domiciliar planeado es un ideal coherente con el estilo de vida, creencias, valores, cultura y se constituye en un derecho reproductivo y sexual. El parto domiciliar es una nueva oportunidad para interactuar con el mundo y con personas que forman parte de la red de apoyo a la pareja en el proceso del nacimiento.
\end{abstract}

DESCRIPTORES: Parto domiciliario. Enfermería obstétrica. Enfermeras obstetrices. Características culturales. Asistencia.

\section{INTRODUCTION}

Pregnancy, delivery, and postpartum are social, singular events, and contemplative and remarkable experiences in the life of a couple, often involving their families and significant others. The delivery may represent a commitment of the contemporary couple to perpetuate life, exercise the right to give birth in a way chosen by them, with those they want, and where they want, in accordance with their personal values and beliefs. It is a potential space of power and knowledge of the couple as they may substantially assume the control of the birth process. The birth initiates a new cycle of organizational development of the family. The way it happens may indicate how the care to the new being will occur, and how the relationship with other members of the family may be maintained. ${ }^{1}$

Delivery and birth are events that may be experienced in a shared manner; they are considered a form of celebration of life, events of the universe of the couple in accordance with their beliefs. These events may involve safety, sensitivity, and intimacy, being affected by the family culture, the type of delivery, and the meaning assigned by those participating in the process. The meanings are built based on the worldview, beliefs, and values that are influenced by the sociocultural context of the individuals or groups, that is, they are not dissociated from the concept of culture that may be read as values, beliefs, rules, and practices of life of a given group, learnt, shared, and transmitted to guide the thought, the decisions, and the actions in a standardized manner. ${ }^{2-4}$

Nowadays, planned home birth arises as a possibility of reconciliation between science and tradition, skills and intuition, pointing to the rapprochement of the natural in the sense of letting nature take action, encouraging the couple to take the leading role in the birth process, with minimum intervention, supported by a nursing team, if necessary. This care modality is based on the thought that the most appropriate place for delivery is the one where the woman feels safe and where the family is restored, the child, mother, and father, previously separated due to the medicalization of labor, in compliance with the technocratic paradigm of birth care. ${ }^{5}$

At home, the participation of other family members and significant others in the birth scenario is nurtured. This type of delivery provides the exchange of affection between father/mother and the baby, and allows the participation of the couple in the event, respecting beliefs, values, and rituals of care that are significant for all the involved people and that has been developed within the collectivity. ${ }^{2,5-7}$ In addition, it may contribute to a more favorable evolution of the delivery. The familiarity of the woman with the home environment may provide less pain sensation as it provides the woman giving birth with a higher level of relaxation and, consequently, lower release of adrenaline and higher release of endorphins, substances produced in states of the central nervous system. ${ }^{6}$

The environmental context of the processes of pregnancy, delivery, and postpartum at home relates to the physical and sociocultural space, the house of the couple (alternative space for the labor and birth), where the care and interpersonal relationships may be established, especially regarding the privacy of the couple and the act of receiving the 
baby in a more respectful and healthier way. The environmental context may also express the interpersonal care, the privacy, the culture with respect to beliefs, values, and worldview of the couple/ newborn (NB) and of the nurse midwives involving holistic-ecological issues..$^{8-9}$

In this perspective, the "Hanami Team: The Flowering of Life", consisting of nurse midwives, assists home delivery in a planned manner, with a view to the needs of the couple and their families, respecting their beliefs and cultural values. Despite the evident growing interest for the theme and its relevance in the areas of obstetrics and neonatology, the implementation and socialization of studies on planned home birth supported by nurse midwives in Brazil remain scarce, pointing out an important gap in knowledge. The lack of studies published on the meaning assigned by couples to home birth is also emphasized. For these reasons, the production of knowledge on this theme is relevant, as well as the understanding of the meaning assigned by couples to the experience of a planned home birth supported by the nurse midwives of the Hanami team.

These aspects, combined with the seven-year experience developed to these patients undergoing this type of delivery justify the relevance of this study, generating the research question: what is the meaning assigned by couples to the experience of a planned home birth supported by the nurse midwives of the Hanami team?

The present study integrates a macroproject entitled "Giving birth and being born in a new time: the meaning of planned home birth supported by the nurse midwives of the Hanami team for couples." In this sense, this study was developed to understand the meaning assigned by couples to the experience of planned home birth supported by the nurse midwives of the Hanami team.

\section{METHOD}

This is a qualitative study, in the form of convergent-care research (CCR). In the qualitative paradigm, it aims at finding characteristics, standards, and meanings of the studied phenomenon. ${ }^{10}$

In CCR, there is an intense connection with the process of providing care while researching, narrowing the relationship between care and research as it may be implemented in the daily activities of nurses, promoting an intentional integration with the care practice in order to solve or minimize problems, implement changes, and introduce innovation to the daily routine. ${ }^{10}$
In $\mathrm{CCR}$, care actions are incorporated in the research and vice-versa. "Doing" and "thinking" occur together, consequently promoting a significant evolution of the practice, aimed at expanding and contributing to the nursing practice. ${ }^{10}$ It is grounded on a type of investigation simultaneously developed with the nursing care practice, therefore its main characteristic is the convergence with this practice. ${ }^{10}$

The methodological character is evidenced in the "dance" of the CCR through the movements of approaching, distancing, and convergence with the practice in order to create overlapping spaces with care. In this process of coming and going, in this dance between research and care practice, the autonomy of each one of these events needs to be respected. ${ }^{10}$

The path taken by the researcher in the CCR follows a thought within this logic: what to do, how to do, why to do, and knowing how to do something. ${ }^{10}$

The CCR was initiated in the first contact with the couples, in the monthly "open meetings" promoted by the Hanami nurses, aiming at introducing the proposal of the planned home birth and clarifying any doubts of the couples and their families. In this meeting, the researcher invited the couples to participate in the study. However, the process was initiated in the first prenatal visit, upon agreement by the couple. The CCR was conducted during the entire care provided by the Hanami team at their homes, including prenatal care, labor, delivery, and immediate postpartum.

The place and context of this study consisted in the homes of the couples that opted for the planned home birth supported by the Hanami team. A total of 30 couples participated in the study, between October 2011 and November 2012, in the area of Florianópolis, Santa Catarina.

The number of individuals was established at data saturation, that is, when the data started to repeat and met the proposed objectives. ${ }^{10}$

The techniques for data collection consisted of participant observation and interview; the latter complementing the first. The mean time spent in the participant observation was 25 hours, distributed in the visits for prenatal, labor, and postpartum. The mean time of the interviews was 30 minutes. These were recorded, and included the following questions: Tell us about your labor. What was the most impressive thing about it? How was the experience of giving birth at home with the support of the nurse midwives of the Hanami team? 
Criteria for inclusion of the couples were: couples aged over 18 years; single gestations, with normal risk; gestational age over 37 weeks and less than 42 weeks, with cephalic presentation; prenatal care with a minimum of 6 visits; full laboratorial exams in the three quarters, and ultrasonography. Exclusion criteria were: couples that had been transferred to the hospital during labor; couples whose newborns presented complications, and mothers that presented physical and/or psychological complications.

The data were recorded through the formal organization of the information by means of diary notes (DN), records of daily happenings; observational notes $(\mathrm{ON})$; theoretical notes $(\mathrm{TN})$, methodological notes $(\mathrm{MN})$; care notes $(\mathrm{CN})$, and interview notes (IN), which were applied in the late or remote postpartum period, depending on each couple. Analysis was conducted in four stages: apprehension, synthesis, theorization, and transference, ${ }^{10}$ aiming to meet the objective of the study. The maintenance of their anonymity was guaranteed through the use of codenames of a flower for each couple.

The apprehension was correlated to the data collection and initial analysis of the information, registered as diary notes and codification of information, with the adaptation of keywords or key-themes that marked the core themes. These procedures were subsequently grouped by similarity of ideal, generating the categories. The synthesis covered the summarization and discussion of the information after a careful reading. The theorization included the interpretation and analysis of data in view of the theoretical framework. The transference involved the period of significance of the findings and results, contextualizing them in similar situations without the intention of generalizations, but with the socialization of single results, justifying adequacies that could be conducted in other realities. ${ }^{10}$

A reflection was performed on the collected data, when possible, concurrently with their collection in the light of the Theory of Culture Care: Diversity and Universality ${ }^{4,11}$ and delivery care models. ${ }^{12-13}$ An in-depth and reflexive look at the field diary led to the analysis and interpretation of the data through a constant coming and going process..$^{10}$

The research project was approved by the $\mathrm{Hu}$ man Research Ethics Committee of the Universidade Federal de Santa Catarina in accordance with protocol 1199 and a Certificate of Presentation for Ethical Consideration, in compliance with the guidelines of Resolution 466/12 of the National Health Council. ${ }^{14}$ The couples were individually instructed on the actions related to the study, including its aim, benefits, and risks. Only after properly informed, they signed a Free and Informed Consent Form.

\section{RESULTS}

\section{Characterization of the couples}

The mean age of the couples participating in the study was 32 years. They had white skin, undergraduate education, lives in common-law marriage, and owned their home. They were vegetarians, spiritualists, self-employed, from Florianópolis and other countries, presenting traces of miscegenation. In the obstetrical universe: women were multiparous (but nulliparous); 13\% were repeating the experience of a planned home birth. Prenatal visits: mean of 14 (with nurses of the Hanami team and with an obstetrician). Postpartum visits with the nurses of the Hanami team: mean of 6 . Indications for home birth came from friends and the internet. The positions chosen for delivery were vertical.

The analysis processes resulted in the design of the category Culturally respectful and sensitive birth and three subcategories.

\section{Culturally respectful and sensitive delivery}

Care in the delivery, respecting the culture in a sensitive way, represents a characteristic of the work of the Hanami team's nurses, who captivated the couples when they sought the team to be cared by them.

Details such as respect and a high level of sensitivity in relation to what is important to the other in care represent powerful tools to satisfy the cared individuals, consisting in premises that every professional should have as a priority in their daily work:

[...] when we began to seek for a home birth we already had the reference of two couples; they told us about the way you worked, but in practice it represented a lot more, because they know how to be sensitive and they insist that everything has to occur as planned... (Couple Primula).

\section{Subcategory 1 - The realization of an ideal}

The planned home birth, considered as an ideal method for couples, is a construction that meets their desire, lifestyle, beliefs, and values. It was consolidated after a positive experience with the labor and birth process in their social and cultural environment, that is, their home.

These couples present a high level of education and information, therefore such search is 
responsible and informed. It is an ideal with solid foundations.

In this context, reports evidencing the position of the couples and their arrangements to overcome the technocratic model are presented, as well as the realization of their ideals, referring them to what may be recognized as the construction of a new time, that is, the delivery is idealized as a dream and a singular opportunity for cultural repatterning and learning, that is, they are couples participating in the holistic model because they want to have their babies at home, when no risk is pointed out. In case of a need for transfer, they want to go to a "humanized maternity hospital".

We wanted privacy, intimacy, safety, respect. We understood the moment of the delivery as something natural, therefore we wanted support to experience it with safety and confidence in those who would be with us and, particularly, intimacy. In our conception, our home is the place where we feel fully comfortable to feel peaceful. Our home reflects what we are, it is our nest, our place (Couple Primula).

[...] We researched a lot to make this decision, in relation to both the place and the team [...] (Couple Fleur-de-lis).

[...] an achievement, a dream, a learning, and one more evidence that there is no other path to be followed by a couple but this, except in cases of emergency, without giving up the scientific evidence [...] (Diary notes of the Couple Rose).

For the couples, the experience of the planned home birth meant the maintenance and strengthening of their authority, as well as an autonomy and domain over the delivery and birth. Also, it meant confidence and strengthening of their power to make choices on how to conduct these special moments in their lives and opt for the support of professionals that recognize their values and beliefs to support their decisions and realization of their ideals.

The construction of this ideal of home birth happened because I wanted Dália to come to this world in a cozy environment. The idea of having strange people around me, of living the most important moment of my life in a place that I see as being so cold and, particularly, the idea of transferring the responsibility of my labor, of my life and Dália's life to an unknown team [...]. The day we went to see the work of the Hanamis [...], it was great! We talked a lot and we felt that they [nurses of the Hanami team] do this following a true vocation... I felt even more confident because my husband was fully convinced (Diary Notes of the Couple Dahlia).

\section{Subcategory 2 - Birth with the family}

The planned home birth also allows an extension of the family, as the supporting friends participating in the process, for several reasons, give a new meaning and strength the family ties.

Wow! The delivery actually changed everything [...] a new life, the creation of a new family. My friends that participated in this process now belong to the family core (Couple Fuchsia).

The couples made explicit the occurrence of a transformation and strengthening in the marital relationship that was initiated in the pregnancy and culminated in the childbirth. In turn, in their social context the women allowed themselves to express their most primitive instincts, their sexuality, and sensuality through behaviors such as screams and groans. Couples that already had children pointed out that the participation of the family in the home birth meant a growth and maturation in the marital relationship, as well as between parents and children.

The delivery meant the family rebirth. We became stronger, connected. As a couple, we fell in love and loved each other even more; we became more intimate and complete as spouses and parents. Our relation with our children became more solid and intense. It was certainly a transforming experience that changed our family structure, changed us, and made us understand more about life (Couple Orchid).

Therefore, the planned home birth is considered a paradigmatic event for women, men, couples, and for the babies. Thus, the emotional environmental context of the birth should present a harmonious characteristic. In this perspective, the professionals supporting the labor would need to be significantly familiar with the physiology of the processes undergone by the women and the baby during the labor, delivery, and postpartum; also, they need the have sensitivity, love life, and provide security to the family, respecting silence and privacy, be attentive and respectful with them, particularly with the baby:

[...] it was an achievement. It was the most amazing moment of my life. When I touched her little head, even before she was born, it was a feeling that I can't describe. I know I will never forget that moment and her little face when she was just born. She is the most important person in my life. It is something that only the universe may provide (Couple Wild Flower).

Men, just like women, are affected by the pregnancy and birth of their children. The inclusion of the figure of the father in the planning of the labor care, delivery, and birth is performed as an 
active participant in the whole process. Moreover, they pose new experiences and new challenges to health professionals, especially nurse midwives, as they need to be also attentive to the male figure in the labor, understanding their fears, expectations, emotions, and responsibilities.

Considering the apprehensions of the present study regarding the experience of men in the home birth, it meant the strengthening of the role of the father and their active inclusion in the birth process.

He participated in all stages of the delivery, helping the nurses, but specially taking care of me, giving me massages, always loving and supporting me. He is a great partner, even in the division of tasks. Today he woke up seven o' clock while I stayed in bed (Couple Hydrangea).

It was the strongest experience I ever lived; it is a strong experience and I am glad that I did it. I suffered with her in every contraction; I was scared for not knowing what to do. I tried to do my part, being with her all the time; but when I saw his little face, I felt like a father, walking through the clouds; I cried. It was a lot of emotion. Now it is a new responsibility; we are in fact a family (Couple Azalea)

Therefore, the man/father perceives the pain in the labor and delivery with a new meaning, such as the suffering necessary to the birth, which should be experienced with his partner.

\section{Subcategory 3 - The choice for their home instead of a hospital}

The couples considered the planned home birth preferable to the hospital environment because it restores the family environment, gives opportunity to the father and the family to participate, allows a natural return, and increases the domain and control of the situation. Therefore it introduces possibilities to expand the freedom and responsibilities of the couple. The planned home birth restores the autonomy and empowerment admittedly enrolled in a broader perspective of rights related to health; in this case, particularly, in the sexual and reproductive right of women and men.

We not even considered a hospital; we are horrified about everything we hear about it. There, women may have a partner, but they remain under the responsibility of the professionals, who decide everything. Even in humanized maternity hospitals, we heard about a series of violent practices, for example: they climbed on the woman's belly, they cut the perineum, she received serum to generate more contractions. Poor father, just stays there without doing anything, fearing to be expelled from the environment for disturbing them. Of course, we know we have to be prepared for a Plan B, to be transferred, so we had our bags ready and simulated the experience of a Caesarean operation, we worked the aspect of the cerebral delivery [...]. We went to know the maternity hospitals. We couldn't, despite all the accommodations. Never, it would never be like our home. We talked for days about the possibility of being transferred, but we would have the support of the nurses (Diary Notes of the Couple Calla Lily).

In fact I had never thought of myself giving birth in a hospital, it never crossed my mind, you know, and I don't know where the idea of giving birth at home came from. I have always thought that it should be this way. I have never thought differently. And then everything just happened, I was here on the island, and there was the Hanami Team (Couple Fuchsia).

The different cultures point out a convergence with the Brazilian couples of the present study as they present similar, convergent reasons to avoid the delivery at a hospital, that is, fear of hospitals and obstetric violence. However, when a transference to a hospital is necessary, the support of the professionals and family members is critical so that the couple feels safe, not only in relation to the outcome but also to the understanding and repatterning of the experience.

\section{DISCUSSION}

The culturally respectful and sensitive delivery points out a parturition scenario desired by the couples, as well as an intimate, cozy, familiar environment in which the professionals selected to participate in this special moment are able to understand the worldview, beliefs, values, care rituals, and the meanings assigned to the moments of the labor and birth. Therefore, it is imperative that the provided care is culturally responsible, respectful, sensitive, and competent. ${ }^{7,15}$ In this sense, the nurses of the Hanami Team work with presuppositions based on the Theory of Diversity and Universality, ${ }^{4}$ by seeking a cultural repatterning in the process of providing care to these couples, thus strengthening a care based on a model rebuilt or changed to support the couples to change/recognize the health or life patterns in order to make the labor process meaningful or consistent with its current meaning. Therefore, such care with a new meaning is striking in their lives. ${ }^{4,16}$

The couples of the study seek and live the counterculture of the technocratic model of labor care that perpetuates technological and biologist rituals at the labor based on values that intensify the 
female impotence by means of the indiscriminate and often irrational use of technology that favors the mastery of machines over the bodies and individual and collective beliefs, culminating in what may be called birth industry. ${ }^{13}$

At their own home, the couple feels safe, especially for being surrounded by people who love them; the couple also experiences the freedom to express their feelings, the legitimacy of their behavior, the understanding and clarification of their doubts, and the respect in relation to their decisions and desires. ${ }^{17}$

In this perspective, the home was also understood as a space that strengthens the meeting of the couple with their phylogenetic roots. ${ }^{18-19}$ The relationship of this couple with the Hanami Team was crucial in the option for the planned home birth. Some couples pointed out that the idea of safety is related to privacy, particularly to the relationship developed with the professionals, a relationship that should start in the prenatal care.

At the moment of the delivery, the couples that opted for a planned home birth had the opportunity to be accompanied by their children, friends, or family members who supported their decision, as well as by the nurse midwives of the Hanami team, whose care is based on the concepts of the Theory of Cultural Care: Diversity and Universality, ${ }^{4,11}$ and on the labor care models. ${ }^{12-13}$ since its creation in 2006.

The couple often prefers not to expose to their families the decision in relation to the place where the labor will occur, especially when the family members show resistance to the home birth, even planned deliveries. Therefore, they seek support in their friends that share this idea, requesting the presence of the loved ones at the moment of the delivery. For these couples, the planned home birth means the recognition and expansion of their nuclear family, as it includes those people from their social relationships that become more intimate and closer to them as a result of sharing the same ideal of the planned home birth, bringing up the configuration of other subjectivities. ${ }^{20}$

The critical perspective of the medicalization of labor that is present in the countercultural movements is taken up in their own way by the practitioners of the planned home birth, both in the speech and in the practice; it goes beyond the personal, social, and cultural dimensions, also including the transcendence dimension. The notion of autonomy cultivated by the couples is not limited to the rational and imperative management of their own lives, as it is also inserted in a higher cosmic order, possibly representing a conflict before the modern conception of individual as owner of the themselves and their will. ${ }^{21-22}$ The study also points out that both man and woman has the possibility of becoming a couple of parents when there is mutual support, that is, complicity between them. ${ }^{23}$

Therefore, the parents may also experience contradictory feelings before the fear of the unknown, the unexpected, the responsibilities inherent to their new role and the emotions triggered by this moment. The transition to parenthood is a moment of significant emotional vulnerability to both the mother and the father. ${ }^{24}$

In the planned home birth the man-father has higher possibility to live their role to the full in relation to what would be their participation as companion in the current institutional labor care model, despite all the advances in the humanized birth model. ${ }^{25}$

Women that decided to give birth at home based their decision on the existing intuitive view. In Baloch, Iran, the women opted for their home for trusting their own intuition, in their midwife, and in the psychosocial support of their families to transfer them to the hospital in case of any complications. ${ }^{26}$

In this study the planned home birth instead of the hospital birth was found to be similar to the results presented in another study that points out that the women seek information in order to make a conscious choice and position themselves against the hospital care model. The listed reasons evidence that the acquisition of knowledge is a basic condition to support the decision of giving birth at home, and reveals a significant dissatisfaction of these women with the current institutionalized model of labor care. ${ }^{27}$

In the Brazilian context, the planned home birth is virtually clandestine, as women, men, and couples that opt for this alternative need to financially and emotionally support their choice. The fact that the planned home birth is still not contemplated in the public health policies and consequently the reference and counter-reference systems do not work ${ }^{28-29}$ weakens the care for the women, their families, and the professionals that are providing care.

The absence of the Ministry of Health in the debate on the right to choose the place of birth causes isolation of women in a period that is important to count on a wide protection network, including a partner, family, friends, professionals, and the support of the public health network. This issue results in a lack of guidelines for the health professionals and lack of information and guidance 
for most women, allowing the choice of the place of birth only by those people with higher incomes, thus generating social exclusion. It seems to be necessary that the Ministry of Health promotes the right to choose the place of birth and that such decision is respected and guaranteed as part of the sexual and reproductive right of women, therefore included in the action of the Unified Health System. ${ }^{28-29}$

The scarce scientific production in this area is a limitation of the present study. Maybe this is one of the factors for a higher sedimentation of this practice. Moreover, the need to discuss this situation with professional entities is pointed out, especially in relation to those that congregate doctors, as well as the inclusion of this theme in the training of health professionals.

\section{CONCLUSION}

The conceptual frameworks of this study used in the professional practice of the nurse midwives of the Hanami eam: the flowering of life enabled the recognition that for the studied couples the planned home birth provided the opportunity to recognize that giving birth in a new time allowed new meanings, not only in relation to the labor but also in their lives and the lives of their family members.

The planned home birth emerged as an opportunity to empower the couple to take on the leading role in the labor and birth as a differentiated way of receiving their newborn, in a harmonious and peaceful way, promoting the strengthening of the family and marital relationship.

In addition, it is a striking moment that allowed the expression of the instincts and feelings of the woman, as well as the recognition of these strengths by their partner, a "new" father, thus reconfiguring the roles related to the responsibilities regarding the maternity and paternity.

This new chance to interact with the world and with people that are part of the support network of the couple in the birth process particularly meant a more humanized way to welcome a new life and face the birth, rescuing the old, giving it a new form as it is conducted in a safe way by competent professionals that work with theoretical and methodological foundations. Many people see it as a qualitative leap in the evolution of the human species in the threshold of the emergence of a new humanity.

Despite occasional cases requiring transference to a hospital, the home birth is considered by the couples as the preferred place of delivery, instead of a hospital, and represents an opportunity to the father and the family to actively participate, with increased control of the situation, freedom, and the responsibility of the couple as well as in the exercise of their sexual and reproductive rights.

The positive experience of the couples realized the meaning that the planned home birth is an ideal consistent with the lifestyle, beliefs, and values. The couples oppose the technocratic model of labor care in force in Brazil by seeking professional care and support based on a holisticecological-cultural model that values and gives a higher meaning to the experience of giving birth and being born in a new time.

This study may help health professionals, couples, and society to have a better understanding of why the option for the planned home birth has been highly recommended in the contemporary world, and subsidize the development of the cultural care in the obstetric care for nursing and the multidisciplinary health team.

It is also important to mention that despite the meanings assigned by the couples demonstrating satisfaction in relation to the planned home birth, the fact that the current Brazilian public policies in the field of sexual and reproductive health still do not recognize the planned home birth as a possibility in the obstetric care (as it is recognized abroad) generates concerns.

Therefore, the conduction of studies with health professionals, women, and companions in the public and private sectors, as well as productions relating the planned home birth with breastfeeding, mental health of the children, family and marital relationship, and others related to the quality of life and health is recommended.

\section{REFERENCES}

1. Burigo RA. Planejando o parto no domicílio e tendo que parir no hospital: significados da experiência para as mulheres [dissertação]. Florianópolis: Universidade Federal de Santa Catarina, Programa de Pós-Graduação em Enfermagem; 2013. 139

2. Pimenta LF, Silva SD, Barreto CN, Ressel LB. The culture interfering on the wish about the type of parturition. J Res Fundam Care. 2014; 6(3):987-97.

3. Pinheiro BC, Bittar CML. Expectativas, percepções e experiências sobre o parto normal: relato de um grupo de mulheres. Fractal Rev Psicol. 2013; 25(3):585-602.

4. Leininger M. Culture care diversity and universality: a theory of nursing. New York (US): National League for Nursing Press; 1991.

5. Lessa HF, Tyrrell MAR, Alves VH, Rodrigues DP. Information for the option of planned home birth: 
women's right to choose. Texto Contexto Enferm [Internet]. 2014 [cited 2016 Oct 17]; 23(3):665-72. Available from: http://dx.doi.org/10.1590/010407072014000930013

6. Odent M. Primal health research: four essays. J Prenat Perinat Psychol Health. 2011; 26(2):1-10.

7. Feyer ISS, Monticelli M, Boehs AE, Santos EKA. Rituais de cuidado realizados pelas famílias na preparação para a vivência do parto domiciliar planejado. Rev Bras Enferm. 2013; 66(6):879-86.

8. Koettker JG, Brüggemann OM, Dufl at RM. Partos domiciliares planejados assistidos por enfermeiras obstétricas: transferências maternas e neonatais. Rev Esc Enferm USP. 2013; 47(1):15-21.

9. Ministério da Saúde (BR). Saúde sexual e saúde reprodutiva. Brasília (DF): Ministério da Saúde; 2010.

10. Trentini M, Paim L. Pesquisa convergente-assistencial: um desenho que une o fazer e o pensar na prática assistencial em saúde-enfermagem. Florianópolis (SC): Insular; 2014.

11. Leininger M. Transcultural nursing: concepts, theories and practices. New York (US): Wiley \& Sons; 1978.

12. Davis-Floyd R. The technocratic, humanistic, and holistic paradigms of childbirth. Int J Gynaecol Obstet. 2001; 75(1):S5-S23.

13. Davis-Floyd R, John GS. Del medico al sanador. Buenos Aires (AR): Editorial Creavida; 2004.

14. Ministério da Saúde (BR). Conselho Nacional de Saúde. Resolução 466/12, de 12 de dezembro de 2012. Diretrizes e normas regulamentadoras sobre pesquisa envolvendo seres humanos. Brasília (DF): CNS; 2012.

15. Leininger MM, McFarland MR. Culture care diversity and universality: a worldwide nursing theory. New York (US): Rock City Books; 2006.

16. Leininger M. Teoria do cuidado transcultural: diversidade e universalidade. In: Anais do I Simpósio Brasileiro de Teorias de Enfermagem. 1985 May 20-24, Florianópolis, Santa Catarina; 1985. p. 255-70.

17. Frank TC, Pelloso SM. A percepção dos profissionais sobre a assistência ao parto domiciliar planejado. Rev Gaúcha Enferm. 2013; 34(1):22-9.
18. Odent M. Fisiologia do parto: a gênese do homem ecológico. São Paulo (SP): Tao; 1981.

19. Boainain E. Tornar-se transpessoal: transcendência e espiritualidade. São Paulo (SP): Summus editorial, 1999.

20. Carneiro R. Parto domiciliar: ressignificação do doméstico e cronotopías da intimidade. In: Anais do XXV Simpósio Nacional de História ANPUH. 2009 Jul 12-17. Fortaleza, Ceará; 2009. p. 12-21

21. Velho MB, Santos EKA, Collaço VS. Parto normal e cesárea: representações sociais de mulheres que os vivenciaram. Rev Bras Enferm. 2014 mar-abr; 67(2):282-9.

22. Carneiro R. Em nome de um campo de pesquisa: antropologia(s) do parto no Brasil contemporâneo. Vivência: Rev Antropologia. 2014; 1(44):11-22.

23. Gutman L. A maternidade e o encontro com a própria sombra. Rio de Janeiro: Best Seller Ltda; 2010.

24. Garcês MMF. Vivências da figura paterna no trabalho de parto e nascimento no processo de transição para a parentalidade [dissertação] Porto (PT): Escola Superior de Enfermagem; 2011. 130 p.

25. Souza SRRK, Gualda, DMR. The experience of women and their coaches with childbirth in a public maternity hospital. Texto Contexto Enferm [Internet]. 2016 [cited 2016 Oct 17]; 25(1):1-9. Available from: http:/ / dx.doi. org/10.1590/0104-0707201600004080014

26. Abed Saeedi Z, Ghazi Tabatabaie M, Moudi Z, Vedadhir AA, Navidian A. Childbirth at home: a qualitative study exploring perceptions of risk and risk management among Baloch women in Iran. Midwifery. 2013; 29(1):44-52.

27. Sanfelice CFO, Shimo AKK. Parto domiciliar: compreendendo os motivos dessa escolha. Texto Contexto Enferm. 2015 Jul-Set; 24(3):875-82.

28. Castro, CM. Os sentidos do parto domiciliar planejado para mulheres do município de São Paulo, São Paulo. Cad Saúde Colet. 2015; 23(1):69-75.

29. Mattos DV, Vandenberghe L, Martins CA. O enfermeiro obstetra no parto domiciliar planejado. Rev Enferm UFPE [Internet]. $2016 \mathrm{fev}$ [cited 2016 Oct 17]; 10(2):568-75. Available from: 10.5205/reuol.855774661-1-SM1002201625. 